\title{
Nesfatin-1 as a New Potent Regulator in Reproductive System
}

\author{
Jinhee Kim and Hyunwon Yang ${ }^{\dagger}$ \\ Dept. of Bioenvironmental Technology, College of Natural Sciences, Seoul Women's University, \\ Seoul 139-774, Korea
}

\begin{abstract}
Nesfatin-1 is a recently discovered anorexigenic peptide which is distributed in several brain areas implicated in the feeding and metabolic regulation. Recently, it has been reported that nesfatin-1 is expressed not only in brain, but also in peripheral organs such as digestive organs, adipose tissues, heart, and reproductive organs. Nesfatin-1 is markedly expressed in the pancreas, stomach and duodenum. Eventually, the nesfatin-1 expression in the digestive organs may be regulated by nutritional status, which suggests a regulatory role of peripheral nesfatin-1 in energy homeostasis. Nesfatin-1 is also detected in the adipose tissues of humans and rodents, indicating that nesfatin-1 expression in the fat may regulate food intake independently, rather than relying on leptin. In addition, nesfatin-1 is expressed in the heart as a cardiac peptide. It suggests that nesfatin-1 may regulate cardiac function and encourage clinical potential in the presence of nutritiondependent physio-pathologic cardiovascular diseases. Currently, only a few studies demonstrate that nesfatin-1 is expressed in the reproductive system. However, it is not clear yet what function of nesfatin-1 is in the reproductive organs. Here, we summarize the expression of nesfatin-1 and its roles in brain and peripheral organs and discuss the possible roles of nesfatin-1 expressed in reproductive organs, including testis, epididymis, ovary, and uterus. We come to the conclusion that nesfatin-1 as a local regulator in male and female reproductive organs may regulate the steroidogenesis in the testis and ovary and the physiological activity in epididymis and uterus.
\end{abstract}

Key words : Epididymis, Nesfatin-1, Ovary, Testis, Uterus

\section{INTRODUCTION}

Nucleobindin precursor protein, which was identified for the first time in the human and mouse cell lines, is known to have two isotypes, nucleobindin 1 (NUCB1) and nucleobindin 2 (NUCB2) (Miura et al., 1992; Kanai \& Tanuma, 1992; Barnikol-Watanabe et al., 1994). This precursor protein contains multiple functional domains including a signal peptide on the N-terminal side, a leucine/isoleucine rich region, a DNA binding domain and a putative nuclear targeting signal, while the second half contains two $\mathrm{Ca}^{2+}$-EF-hand motifs and a leucine zipper motif in the C-terminal region (Barnikol-Watanabe et al., 1994). However, NUCB2 only functions physio-

\footnotetext{
Corresponding author: Hyunwon Yang, Dept. of Bioenvironmental Technology, Seoul Women's University, Seoul 139-774, Korea. Phone: +82-2-970-5662, Fax: +82-2-970-5974, E-mail: hwyang@swu.ac.kr
}

logically in humans and rodents (Miura et al., 1992). NUCB2 produces nesfatin-1 (residues 1-82), nesfatin-2 (residues 85-163), and nesfatin-3 (residues 166-396) by the enzyme pro-hormone convertase (PC)-1/3 after putative post-translational processing. Until now, a physiological activity has only been demonstrated for nesfatin-1 (Oh-I et al., 2006; Stengel et al., 2012a). The nesfatin-1 molecule is composed of three domains: N-terminal (N23), middle part (M30) and C-terminal (C29). The M30 active core appears to play the key role in the induction of physiological effects of this peptide, and especially in its anorectic responses (Pałasz et al., 2012).

\section{Central Expression of Nesfatin-1}

\section{Expression of nesfatin-1 in the brain}

Nesfatin-1 is initially known to be expressed in the rat hypothalamic nuclei for ingestive behavior regulation 
such as the paraventricular nucleus of the hypothalamus (PVN), supraoptic nucleus (SO), arcuate nucleus (ARC), lateral hypothalamic area (LHA), zona incerta and the nucleus of the solitary tract in rats (Oh-I et al., 2006). Furthermore, nesfatin-1 also exists in the additional hypothalamic nuclei, pituitary, cerebrospinal fluid and brain stem, including rostral raphe pallidus (rRPa), EdingerWestphal nucleus (EW), locus coeruleus (LC), ventrolateral medulla (VLM) and the dorsal motor nucleus of the vagus nerve (Brailoiu et al., 2007; Chen et al., 2012; Foo et al., 2008; Fort et al., 2008; Goebel et al., 2009a; Goebel et al., 2011; Kohno et al., 2008; Stengel et al., 2009c; Stengel et al., 2010b; Xu et al., 2009). Interestingly, nesfatin-1 immunoreactive neurons co-localize with a number of brain transmitters, such as the melanin-concentrating hormone $(\mathrm{MCH})$, cocaine-and amphetamine-regulated transcript (CART)/pro-opiomelanocortin (POMC), $\alpha$-melanocytestimulating hormone ( $\alpha-\mathrm{MSH})$, mammalian target of rapamycin (m-TOR), vasopressin, oxytocin, neuropeptide Y (NPY), Agouti-related protein (AgRP), somatostatin, growth hormone-releasing hormone (GHRH), thyrotropinreleasing hormone (TRH), corticotropin-releasing factor (CRF) and neurotensin (Brailoiu et al., 2007; Foo et al., 2008; Fort et al., 2008; Inhoff et al., 2010; Kohno et al., 2008; Li et al., 2012; Maejima et al., 2009; Okere et al., 2010).

\section{Roles of nesfatin-1 in the brain}

\section{1) Regulation of food intake}

The various studies were performed about the central action of nesfatin-1. The initial report showed that the post third ventricular $(3 \mathrm{v})$ or fourth ventricle $(4 \mathrm{v})$ injection of nesfatin-1 decreases dark phase food intake in freely fed rats (Oh-I et al., 2006). Similarly, injection of nesfatin-1 into the lateral brain ventricle (intracerebroventricular, icv) of ad libitum fed rats reduced the dark phase food intake and controlled the water drinking (Shimizu et al., 2009a; Stengel et al., 2009a; Stengel et al., 2010a; Yosten \& Samson, 2009; Yosten et al., 2012). Likewise, microinjection of nesfatin-1 directly into the PVN also suppresses the dark phase food intake in male rats (Maejima et al., 2009; Stengel et al., 2009a).

Nesfatin-1, which is released from the POMC/CART neurons, directly inhibits the NPY/AgRP neurons, causing their hyperpolarization, through the ATP-dependent potassium channels Kir6.2. There are some suggestions that the hyperpolarization of orexigenic ARC neurons can be a key phenomenon in anorexia, induced by nesfatin-1 (Price et al., 2008). Another study provided compelling evidence for the involvement of an oxytocin pathway in nesfatin-1's inhibitory effect on food intake. An oxytocin receptor antagonist injected into the hindbrain at the level of the $4 \mathrm{v}$ blocked the food intake reducing effect of nesfatin-1 injected into the PVN (Maejima et al., 2009). Likewise, an oxytocin antagonist injected icv blocks the food intake suppressing effects of icv nesfatin-1 and $\alpha$-MSH (Yosten \& Samson, 2010). On the other hand, these pathway of nesfatin-1's anorexigenic action is independently with central leptin signaling as suggested by the finding that nesfatin-1's central food intake reducing effect is retained in leptin receptor deficient rats (Oh-I et al., 2006).

\section{2) Brain activation by stressors}

Some studies demonstrated that central nesfatin-1 may play a role in the response to stress, such as abdominal surgery, inflammatory stimulus, intraperitoneal injection of lipopolysaccharide and eating disorder (Bonnet et al., 2009; Dayas et al., 1999; Goebel et al., 2009b; Merali et al., 2008; Okere et al., 2010; Stengel et al., 2010b; Stengel et al., 2011; Xu et al., 2010). These findings are based on the result of that icv nesfatin-1 exerts a CRF receptor-dependent effect in food intake and the central distribution in forebrain, hindbrain and spinal autonomic nuclei, along with the expression of nesfatin-1 in CRF neuron (Foo et al., 2008; Stengel et al., 2009a). In addition, the brain activation by stress is associated with the co-localization of nesfatin-1 immunoreactive 
neurons and brain transmitters, such as a neurotensin, urocortin and serotonin (Stengel et al., 2009a).

\section{3) Effect of anti-inflammatory and anti-apoptosis}

Recent two studies reported that effects of nesfatin-1 as an anti-inflammatory and anti-apoptotic peptide in subarachnoid hemorrhage ( $\mathrm{SAH}$ )-induced rats (O"zsavci et al., 2011; Tang et al., 2012). These findings suggest that nesfatin-1 exerts neuroprotection in SAH-induced injury in rats by inhibiting neutrophil infiltration and nuclear factor kappa-B-dependent inflammatory responses. Furthermore, nesfatin-1 may lessen caspase-3-mediated neuronal cell apoptosis after traumatic brain injury (O" zsavci et al., 2011; Tang et al., 2012).

\section{Peripheral Expression of Nesfatin-1}

\section{Expression of nesfatin-1 and its roles in digestive organs}

Large amounts of the nesfatin-1 expression were detected in the digestive organs as well as the hypothalamus and brainstem. In particular, nesfatin-1 is markedly expressed in the pancreas, stomach and duodenum of rodent and canine (Gonkowski et al., 2012; Iwasaki et al., 2012; Mohan \& Unniappan, 2012; Osaki et al., 2012; Stengel et al., 2009c; Stengel \& Taché, 2012; Zhang et al., 2010).

In the pancreas, nesfatin-1 is located in rat islet betacells (Gonzalez et al., 2009) and secreted by high glucose stimulation in vitro (Foo et al., 2010; Gonzalez et al., 2011a). A certain study has reported that intravenous administration of nesfatin-1 has anti-hyperglycemic effects in hyperglycemic $d b / d b$ mice ( $\mathrm{Su}$ et al., 2011). However, this reduction in blood glucose levels was not observed in non-hyperglycemic animals and appears to be insulindependent (Gonzalez et al., 2012a; Su et al., 2011). Furthermore, nesfatin-1 enhances glucose-stimulated insulin secretion (GSIS) in mouse pancreatic beta-cells and rat pancreatic islets (Gonzalez et al., 2011b; Gonzalez et al., 2012a; Nakata et al., 2011). This effect is known to be mediated by an increase in intracellular calcium through L-type calcium channels (Nakata et al., 2011). Both calcium free saline and the L-type calcium channel blocker, nitrendipine, inhibit nesfatin-1 potentiation of insulin secretion in the presence of glucose. The mechanism by which nesfatin-1 enhances GSIS is unclear, however, it may be independent of the signaling pathways of glucagon-like peptide-1 (GLP-1), GIP and pituitary adenylate cyclase-activating polypeptide (PACAP) (Nakata et al., 2011). In accordance with the glucose-dependent insulinotropic effects of nesfatin-1 in vitro, an oral glucose tolerance test in ad libitum fed rats infused with nesfatin-1 produced significant increases in circulating insulin levels (Gonzalez et al., 2011a; Gonzalez et al., 2012a). Most recently, a certain paper reported that the icv nesfatin-1 results in increased insulin signaling through Akt kinase (Akt)/AMP kinase (AMPK)/target of rapamycin complex (TORC) 2 pathway, suggesting a potential mechanism for increased insulin sensitivity (Yang et al., 2012). These reports provide the evidence that the presence of nesfatin-1 within the pancreatic islets may be associated with glucose homeostasis.

In addition, nesfatin-1 immunosignals are mainly localized in mucosal endocrine X/A-like cells of the stomach, within a distinct sub-population of vesicles different from those containing the orexigenic hormone ghrelin, suggesting differential regulation and release of ghrelin and nesfatin-1 (Li et al., 2012; Stengel et al., 2009c; Stengel \& Taché, 2010). The fasting for $24 \mathrm{~h}$ decreases NUCB2 mRNA expression in gastric mucosa and significantly reduces nesfatin-1 plasma revels in rats (Stengel et al., 2009a). Furthermore, nesfatin-1, which is released from the synaptic endings of the vagus nerve, has an impact on secretory and motor activity of the gastrointestinal tract and regulates the course of digestive functions (Goebel et al., 2009a; Stengel et al., 2009b; Xia et al., 2012). Interestingly, a recent paper has been demonstrated that pretreatment with capsaicin (to block autonomic $\mathrm{C}$ fibers) abolished the food intake reduction 
caused by peripheral nesfatin- 1 injection. These findings indicate a putative role of vagal afferents in peripheral nesfatin-1 signaling to the brain centers (Shimizu et al., 2009c).

To date, a few studies have focused on nesfatin-1 in the human digestive system. Circulating levels of nesfatin-1 were significantly reduced in fasted type-2-diabetic patients compared to healthy subjects and type-1-diabetic patients. In addition, intravenous infusion of glucose significantly elevated basal nesfatin-1 levels in healthy adults ( $\mathrm{Li}$ et al., 2012). However, circulating nesfatin-1 levels were not altered under an oral glucose tolerance test (Tsuchiya et al., 2010). Interestingly, circulating nesfatin-1 levels were significantly lower in patients with restricting-type anorexia nervosa (Ogiso et al., 2011). These results demonstrate that nesfatin-1 expression in the digestive organs is regulated by nutritional status, suggesting a potential role of peripheral nesfatin-1 in energy metabolism.

\section{Expression of nesfatin-1 and its roles in adipose tissues}

Nesfatin-1 was detected in the adipose tissues of humans and rodents, showing that it was expressed more in the subcutaneous than in the visceral adipocytes (Ramanjaneya et al., 2010). In experiments with fat cell lines, nesfatin-1 expression increased exponentially during the process in which the fat progenitor cells differentiate into the mature fat cells (Ramanjaneya et al., 2010). The fact that high nesfatin-1 concentrations are found in the blood of people with high body mass index (BMI) suggests that nesfatin-1 secreted from fat may regulate food intake independently, rather than relying on leptin (Aydin et al., 2009; Li et al., 2010; Ogiso et al., 2011; Ramanjaneya et al., 2010; Shimizu et al., 2009b; Yamawaki et al., 2012). Most recent two reports showed that NUCB2 enhances the suppression of adipose differentiation as a positive modulator of epidermal growth factor (EGF)dependent signals (Tagaya et al., 2012a; Tagaya et al., 2012b).

\section{Expression of nesfatin-1 and its roles in heart}

A few studies have demonstrated that nesfatin-1 protein are expressed in the heart, as a cardiac peptide (Angelone et al., 2012; Mimee et al., 2012; Yosten \& Samson, 2009). Nesfatin-1 directly affects myocardial performance, possibly involving particulate guanylate cyclase-linked natriuretic peptide receptor A (pGC-linked NPR-A), pGC/ the protein kinase $\mathrm{G}(\mathrm{PKG})$, and extracellular signalregulated kinases1/2 (ERK1/2) pathway (Mimee et al., 2012). In particular, nesfatin-1 protects the heart against ischemia/reperfusion (I/R) injury and this protection involves multiple prosurvival kinases such as PKC, ERK1/2, signal transducer and activator of transcription 3, and mitochondrial $\mathrm{K}_{\text {ATP }}$ channels (Mimee et al., 2012). These results pave the way to include nesfatin-1 in the neuroendocrine modulators of the cardiac function, also encouraging the clarification of its clinical potential in the presence of nutrition-dependent physio-pathologic cardiovascular diseases.

\section{Expression of Nesfatin-1 in Reproductive System}

To date, a few studies have focused on nesfatin-1 in the mouse reproductive system. It is not clear yet whether nesfatin-1 is expressed in the mouse reproductive system and if the binding site of nesfatin-1 protein exists in the reproductive organs. Several studies demonstrated so far that the nesfatin-1 expression and its binding sites are found in the male and female reproductive organs.

\section{Expression of nesfatin-1 in male reproductive organs}

Several recent studies showed the expression of nesfatin-1 in the male reproductive system of human and rodent (García-Galiano et al., 2010; García-Galiano et al., 2012; Kim et al., 2011a). In the testis, nesfatin-1 was localized in the interstitial cells, including the Leydig cells between the seminiferous tubules (Fig. 1A). Leydig cells produce and secrete testosterone, androstenedione, and dehydroepiandrosterone (DHEA) by cholesterol desmolase by 
which cholesterol changes to pregnenolone after stimulation of LH secreted from the pituitary (Akingbemi et al., 2004). LH receptors on Leydig cell membrane play a critical role in the steroidogenesis and the number of them is increased by prolactin resulting increasing LHmediated response (Dufau, 1988). Leydig cells are also known to produce oxytocin and vitamin C (Kukucka et al., 1992), suggesting that they may play as local regulators to control the function of Leydig cells. The fact that Leydig cells express nesfatin-1 protein proposes that nesfatin-1 also has an important role in testicular function as one of local regulators similar to other proteins present in the testis. On the other hand, nesfatin-1 binding sites were displayed at boundary cells in the tunica albuginea of the testis (Fig. 1B). These results support that paracrine signaling by nesfatin-1 between

A.
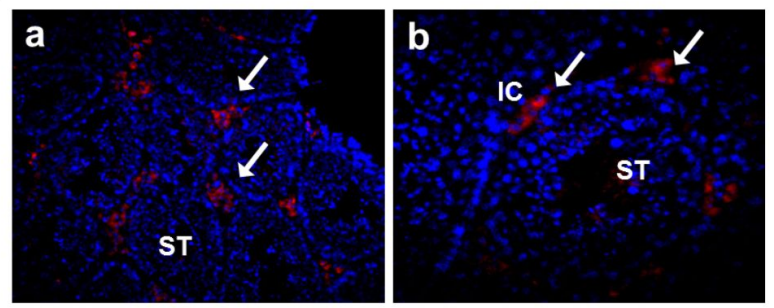

B.
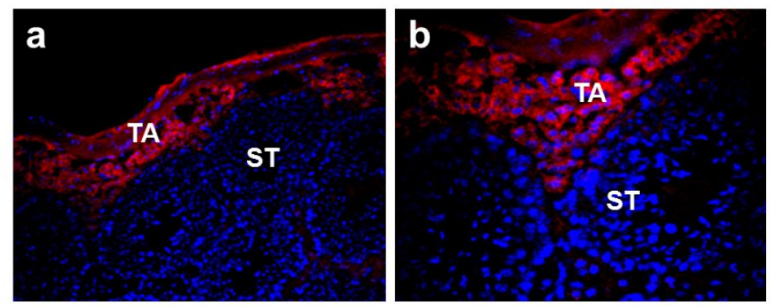

Fig. 1. The localization of nesfatin-1 protein and its binding sites in mouse testis. (A) Testis section was stained with anti-nesfatin-1 antibody to localize nesfatin-1. Nesfatin-1 was expressed within the interstitial cells, including the Leydig cells between the seminiferous tubules. a: $200 \times$; b: $400 \times$. (B) Testis section was stained with biotinconjugated nesfatin-1 and Alexa flour 594-conjugated streptavidin to detect the nesfatin-1 binding sites. Nesfatin-1 binding sites were localized at boundary cells in tunica albuginea. a: 200×; b: 400×. (ST, seminiferous tubule; IC, interstitial cell; TA, tunica albuginea) the Leydig cells and the boundary cells of tunica albuginea may regulate the steroidogenesis and spermatogenesis. In addition, we demonstrated that large amounts of nesfatin- 1 expression were detected in the mouse epididymis as well as the testis (Kim et al., 2011a). Immunohistochemistry results displayed that nesfatin-1 was expressed at the columnar epithelium (Fig. 2A). Nesfatin-1 binding sites were also localized at the columnar epithelium (Fig. 2B). The fact that columnar epithelial cells in the epididymis express both nesfatin-1 protein and its binding sites proposes that nesfatin-1 may play a role as a local regulator by autocrine signaling to regulate the sperm maturation and motility. Furthermore, nesfatin-1 expression levels of the testis and epididymis were increased by the gonadotropin injection (Kim et al., 2011a). This

A.
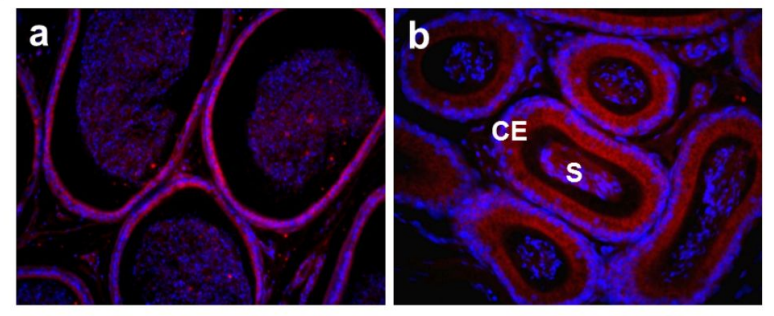

B.
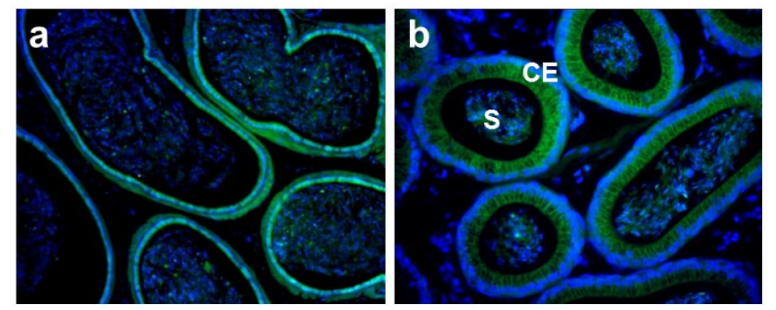

Fig. 2. The localization of nesfatin-1 protein and its binding sites in mouse epididymis. (A) Epididymis section was stained with anti-nesfatin-1 antibody to localize nesfatin-1. Nesfatin-1 was expressed at the columnar epithelium and some of the spermatozoa in the lumen. a: 200×; b: 400×. (B) Epididymis section was stained with FITC-conjugated nesfatin-1 to detect the nesfatin-1 binding sites. Nesfatin-1 binding sites were localized at the columnar epithelium and some of the spermatozoa in the lumen. Interestingly, nesfatin-1 binding sites were detected at same location as nesfatin-1 expression sites. a: 200×; b: 400×. (S, spermatozoa; $\mathrm{CE}$, columnar epithelium) 
result demonstrates that nesfatin-1 produced in the male reproductive system is regulated by gonadotropin secreted by the pituitary like other proteins produced in the testis under gonadotropin control.

\section{Expression of nesfatin-1 in female reproductive organs}

In this year, Gonzalez et al. (2012b) demonstrated the expression of nesfatin-1 protein in the fish ovary and hypothalamus, suggesting the regulatory effects of nesfatin-1 on the hypothalamo-pituitary-ovarian (HPO) axis of fish. In the ovary of goldfish and zebrafish, nesfatin-1-like immunoreactivity was detected in the

A.
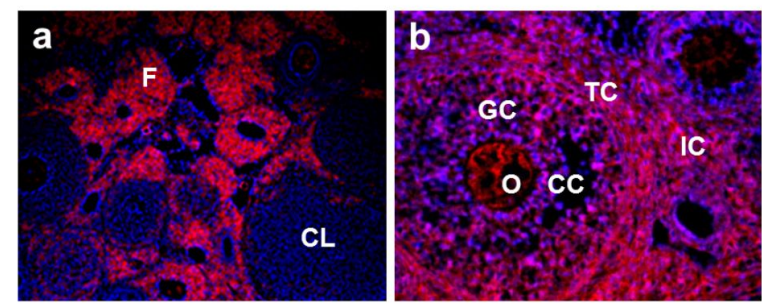

B.
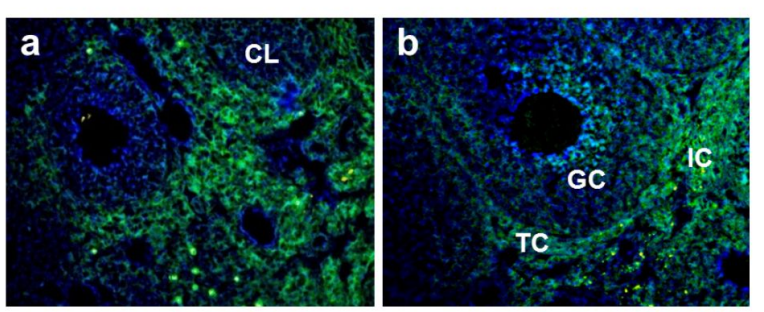

Fig. 3. The localization of nesfatin-1 protein and its binding sites in mouse ovary. (A) Ovarian section was stained with anti-nesfatin-1 antibody to localize nesfatin-1 protein. Nesfatin-1 was expressed in the theca cells around the follicles, the interstitial cells, and the oocytes in some of the follicles. Interestingly, the granulosa cells in the some of the follicles and the cumulus cells around the oocytes were stained with nesfatin-1, but not the corpus luteum. a: 200×; b: 400×. (B) Ovarian section was stained with FITC-conjugated nesfatin-1 to detect the nesfatin-1 binding sites. Nesfatin-1 binding sites were localized in the theca cells and interstitial cells around follicles. Interestingly, some granulosa cells in the follicles were stained with FITC-conjugated nesfatin-1. a, b: 200×. (F, follicle; CL, corpus luteum; O, oocyte; GC, granulosa cells; $\mathrm{CC}$, cumulus cells; IC, interstitial cells; TC, theca cells) follicle cells encircling the oocytes. In addition, a single intraperitoneal injection of synthetic goldfish nesfatin-1 resulted in an acute decrease in the expression of hypothalamic GnRH and serum LH levels (Gonzalez et al., 2012b). Furthermore, our previous papers have shown that nesfatin-1 and its binding sites are expressed in the female mouse reproductive organs (Kim et al., 2010; Kim et al., 2011b). In the ovary, nesfatin-1 was expressed in the theca cells, interstitial cells, and some of oocytes. Interestingly, the granulosa and cumulus cells around the oocytes were stained with nesfatin-1, but not the corpus luteum (Fig. 3A). On the other hand, nesfatin-1 binding sites were detected in the theca cells and interstitial cells around follicles (Fig. 3B). These results suggest that nesfatin-1 may play a role as a local regulator via autocrine and paracrine signaling to regulate the steroid-

A.
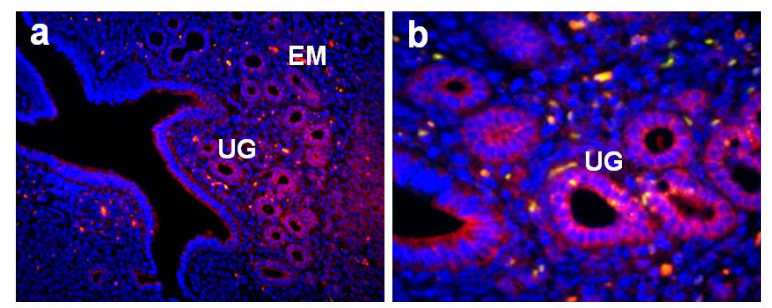

B.
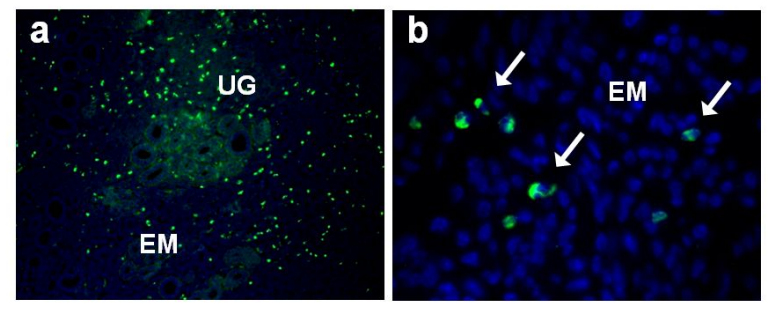

Fig. 4. The localization of nesfatin-1 protein and its binding sites in mouse uterus. (A) Uterine section was stained with antinesfatin-1 antibody to localize nesfatin-1. Nesfatin-1 was expressed on the epithelial cells of endometrium and uterine glands. a: $100 \times$; b: $400 \times$. (B) Uterine section was stained with FITC-conjugated nesfatin-1 to detect the nesfatin-1 binding sites. Nesfatin-1 binding sites were localized in the epithelial cells of uterine glands. Interestingly, neutrophils in the endometrium were stained with FITC-conjugated nesfatin-1 (arrows in b). a: 100×; b: $1,000 \times$. (EM, endometrium; UG, uterine gland) 
ogenesis and energy homeostasis in the ovary. In addition, nesfatin-1 was localized on the epithelial cells of endometrium and uterine glands in the uterus (Fig. 4A). Nesfatin-1 binding sites were displayed in the epithelial cells of uterine glands and neutrophils in the endometrium (Fig. 4B). Neutrophils are known to play an important role in the collapse and recovery of the endometrium (Kaitu'u-Lino et al., 2007). During estrous cycle, neutrophils move from blood into endometrium and the number of them are dramatically increased in the estrous phase (Sonoda et al., 1998; Steffl et al., 2010). Based on these reports, the finding that nesfatin-1 binding sites were localized on the neutrophils suggests that uterine function may be regulated by nesfatin- 1 to attract neutrophils from blood into the endometrium and activate them. In addition, we previously demonstrated that nesfatin-1/NUCB2 expression in the uterus is regulated by estrogen, but not gonadotropin. Its expression levels were significantly increased in the ovariectomized mice treated with $17 \beta$-estradiol, whereas the mice treated with PMSG showed no difference compared to non-treated mice (Kim et al., 2011b). These results suggest that nesfatin-1/NUCB2 expression in the uterus may be regulated by estrogen secreted from the ovary, but not gonadotropin released by the pituitary gland.

\section{CONCLUSION}

Nesfatin-1 protein produced by neurons in the hypothalamus is known to be secreted into cerebrospinal fluid, be controlling appetite and energy metabolism (Oh-I et al., 2006). Recently, it has been reported that nesfatin-1 is expressed in digestive organs such as the stomach and pancreas (Stengel et al., 2009c) and in adipose tissues (Ramanjaneya et al., 2010). To date, little is known about the expression of nesfatin-1 in reproductive system. However, several recent studies demonstrated that nesfatin-1 and its binding sites expressed in the reproductive organs, including testis, epididymis, ovary and uterus. These results suggest that nesfatin- 1 as a new potent regulator in the male and female reproductive organs may regulate the steroidogenesis and gonadal function. Further study is needed in order to elucidate the exact function of nesfatin-1 in the reproductive system.

\section{ACKNOWLEDGEMENT}

This research was supported by a research grant from Seoul Women's University (2011).

\section{REFERENCES}

Akingbemi BT, Sottas CM, Koulova AI, Klinefelter GR, Hardy MP (2004) Inhibition of testicular steroidogenesis by the xenoestrogen bisphenol $\mathrm{A}$ is associated with reduced pituitary luteinizing hormone secretion and decreased steroidogenic enzyme gene expression in rat Leydig cells. Endocrinology 145:592-603.

Angelone T, Filice E, Pasqua T, Amodio N, Galluccio M, Montesanti G, Quintieri AM, Cerra MC (2012) Nesfatin-1 as a novel cardiac peptide: identification, functional characterization, and protection against ischemia/reperfusion injury. Cell Mol Life Sci Epub ahead of print.

Aydin S, Dag E, Ozkan Y, Erman F, Dagli AF, Kilic N, Sahin I, Karatas F, Yoldas T, Barim AO, Kendir Y (2009) Nesfatin-1 and ghrelin levels in serum and saliva of epileptic patients: hormonal changes can have a major effect on seizure disorders. Mol Cell Biochem 328:49-56.

Barnikol-Watanabe S, Gross NA, Gotz H, Henkel T, Karabinos A, Kratzin H, Barnikol HU, Hilschmann N (1994) Human protein NEFA, a novel DNA binding/ EF-hand/leucine zipper protein. Molecular cloning and sequence analysis of the cDNA, isolation and characterization of the protein. Biol Chem Hoppe Seyler 375:497-512. 
Bonnet MS, Pecchi E, Trouslard J, Jean A, Dallaporta M, Troadec JD (2009) Central nesfatin-1 expressing neurons are sensitive to peripheral inflammatory stimulus. J Neuroinflammation 6:27.

Brailoiu GC, Dun SL, Brailoiu E, Inan S, Yang J, Chang JK, Dun NJ (2007) Nesfatin-1: distribution and interaction with a $\mathrm{G}$ protein coupled receptor in the rat brain. Endocrinology 148:5088-5094.

Chen X, Dong J, Jiang ZY (2012) Nesfatin-1 influences the excitability of glucosensing neurons in the hypothalamic nuclei and inhibits the food intake. Regul Pep 177:21-26.

Dayas CV, Buller KM, Day TA (1999) Neuroendocrine responses to an emotional stressor: evidence for involvement of the medial but not the central amygdala. Eur J Neurosci 11:2312-2322.

Dufau ML (1988) Endocrine regulation and communicating functions of the Leydig cell. Annu Rev Physiol 50: 483-508.

Foo KS, Brauner H, Ostenson CG, Broberger C (2010) Nucleobindin-2/nesfatin in the endocrine pancreas: distribution and relationship to glycaemic state. J Endocrinol 204:255-263.

Foo KS, Brauner H, Ostenson CG, Broberger C (2010) Nucleobindin-2/nesfatin in the endocrine pancreas: distribution and relationship to glycaemic state. J. Endocrinol 204:255-263.

Foo KS, Brismar H, Broberger C (2008) Distribution and neuropeptide coexistence of nucleobindin-2 mRNA/ nesfatin-like immunoreactivityin the rat CNS. Neuroscience 156:563-579.

Fort P, Salvert D, Hanriot L, Jego S, Shimizu H, Hashimoto K, Mori M, Luppi PH (2008) The satiety molecule nesfatin-1 is co-expressed with melanin concentrating hormone in tuberal hypothalamic neurons of the rat. Neuroscience 155:174-181.

García-Galiano D, Navarro VM, Gaytan F, Tena-Sempere M (2010) Expanding roles of NUCB2/nesfatin-1 in neuroendocrine regulation. J Mol Endocrinol 45:281-290.
García-Galiano D, Pineda R, Ilhan T, Castellano JM, Ruiz-Pino F, Sánchez-Garrido MA, Vazquez MJ, Sangiao-Alvarellos S, Romero-Ruiz A, Pinilla L, Diéguez C, Gaytán F, Tena-Sempere M (2012) Cellular distribution, regulated expression, and functional role of the anorexigenic peptide, NUCB2/ nesfatin-1, in the testis. Endocrinology 153:1959-1971.

Goebel M, Stengel A, Wang L, Lambrecht NW, Taché Y (2009a) Nesfatin-1 immunoreactivity in rat brain and spinal cord autonomic nuclei. Neurosci Lett 452: 241-246.

Goebel M, Stengel A, Wang L, Taché Y (2009b) Restraint stress activates nesfatin-1-immunoreactive brain nuclei in rats. Brain Res 1300:114-124.

Goebel M, Wang L, Stengel A, Taché Y (2011a) Localization of nesfatin- 1 neurons in the mouse brain and functional implication. Brain Res 1396:20-34.

Gonkowski A, Rychlik A, Nowicki M, Nieradka R, Bulc M, Całka J (2012) A population of nesfatin 1-like immunoreactive (LI) cells in the mucosal layer of the canine digestive tract. Res Vet Sci 93:11191121.

Gonzalez R, Mohan H, Unniappan S (2012a) Nucleobindins: bioactive precursor proteins encoding putative endocrine factors?. Gen Comp Endocrinol 176:341-346.

Gonzalez R, Perry RL, Gao X, Gaidhu MP, Tsushima RG, Ceddia RB, Unniappan S (2011a) Nutrient responsive nesfatin-1 regulates energy balance and induces glucose-stimulated insulin secretion in rats. Endocrinology 152:3628-3637.

Gonzalez R, Reingold BK, Gao X, Gaidhu MP, Tsushima RG, Unniappan S (2011b) Nesfatin-1 exerts a direct, glucose-dependent insulinotropic action on mouse islet beta- and MIN6 cells. Endocrinol 208:9-16.

Gonzalez R, Shepperd E, Thiruppugazh V, Lohan S, Grey C, Chang JP, Unniappan S (2012b) Nesfatin-1 regulates the hypothalamo-pituitary-ovarian axis of fish. Biol Reprod 87:1-11.

Gonzalez R, Tiwari A, Unniappan S (2009) Pancreatic 
beta cells colocalize insulin and pronesfatin immunoreactivity in rodents. Biochem Biophys Res Commun 381:643-648.

Inhoff T, Stengel A, Peter L, Goebel M, Taché Y, Bannert N, Wiedenmann B, Klapp BF, Mönnikes H, Kobelt P (2010) Novel insight in distribution of nesfatin-1 and phospho-mTOR in the arcuate nucleus of the hypothalamus of rats. Peptides 31:257-262.

Iwasaki Y, Yada T (2012) Vagal afferents sense mealassociated gastrointestinal and pancreatic hormones: Mechanism and physiological role. Neuropeptides 46:291-297.

Kaitu'u-Lino TJ, Morison NB, Salamonsen LA (2007) Neutrophil depletion retards endometrial repair in a mouse model. Cell Tissue Res 328:197-206.

Kanai Y, Tanuma S (1992) Purification of a novel B cell growth and differentiation factor associated with lupus syndrome. Immunol Lett 32:43-48.

Kim JH, Kim HS, Kim SM, Yang HJ, Cho HH, Hwang SP, Moon CI, Yang HW (2011a) Expression of nesfatin-1/NUCB2 and its binding site in mouse testis and epididymis. Dev Reprod 15:249-256.

Kim JH, Lee KR, Kim HK, No SH, Yoo HM, Moon CI, Yang HW (2011b) 17beta-estradiol regulates the expression of nesfatin-1/Nucb2 in mouse uterus. Dev Reprod 15:349-357.

Kim JH, Youn MR, Bang SY, Sim JY, Kang HR, Yang HW (2010) Expression of nesfatin-1/NUCB2 and its binding site in mouse ovary. Dev Reprod 14:287-295.

Kohno D, Nakata M, Maejima Y, Shimizu H, Sedbazar U, Yoshida N, Dezaki K, Onaka T, Mori M, Yada $T$ (2008) Nesfatin-1 neurons in paraventricular and supraoptic nuclei of the rat hypothalamus coexpress oxytocin and vasopressin and are activated by refeeding. Endocrinology 149:1295-1301.

Kukucka Mark A, Misra Hara P (1992) HPLC determination of an oxytocin-like peptide produced by isolated guinea pig Leydig cells: stimulation by ascorbate. Arch Androl 29:185-190.

Li QC, Wang HY, Chen X, Guan HZ, Jiang ZY (2010) Fasting plasma levels of nesfatin-1 in patients with type 1 and type 2 diabetes mellitus and the nutrientrelated fluctuation of nesfatin-1 level in normal humans. Regul Pept 159:72-77.

Li Z, Xu G, Li Y, Zhao J, Mulholland MW, Zhang W (2012) mTOR-dependent modulation of gastric nesfatin-1/ NUCB2. Cell Physiol Biochem 29:493-500.

Maejima Y, Sedbazar U, Suyama S, Kohno D, Onaka T, Takano E, Yoshida N, Koike M, Uchiyama Y, Fujiwara K, Yashiro T, Horvath TL, Dietrich MO, Tanaka S, Dezaki K, Oh IS, Hashimoto K, Shimizu H, Nakata M, Mori M, Yada T (2009) Nesfatin-1regulated oxytocinergic signaling in the paraventricular nucleus causes anorexia through a leptin-independent melanocortin pathway. Cell Metab 2009:355-365.

Merali Z, Cayer C, Kent P, Anisman H (2008) Nesfatin-1 increases anxiety- and fear-related behaviors in the rat. Psychopharmacology 201:115-123.

Mimee A, Smith PM, Ferguson AV (2012) Nesfatin-1 influences the excitability of neurons in the nucleus of the solitary tract and regulates cardiovascular function. Am J Physiol Regul Integr Comp Physiol 302:1297-1304.

Miura K, Titani K, Kurosawa Y, Kanai Y (1992) Molecular cloning of nucleobindin, a novel DNAbinding protein that contains both a signal peptide and a leucine zipper structure. Biochem Biophys Res Commun 187:375-380.

Mohan H, Unniappan S (2012) Ontogenic pattern of nucleobindin-2/nesfatin-1 expression in the gastroenteropancreatic tissues and serum of Sprague Dawley rats. Regul Pept 175:61-69.

Nakata M, Manaka K, Yamamoto S, Mori M, Yada T (2011) Nesfatin-1 enhances glucose-induced insulin secretion by promoting $\mathrm{Ca}^{2+}$ influx through L-type channels in mouse islet beta-cells. Endocr J 58: 305-313. 
O"zsavci D, Ersahin M, Sener A, O“zakpinar O”B, Toklu HZ, AkakIn D, Sener G, Yegen BC (2011) The novel function of nesfatin-1 as an anti-inflammatory and anti-apoptotic peptide in subarachnoid hemorrhageinduced oxidative brain damage in rats. Neurosurgery 68:1699-1708.

Ogiso K, Asakawa A, Amitani H, Nakahara T, Ushikai M, Haruta I, Koyama K, Amitani M, Harada T, Yasuhara D, Inui A (2011) Plasma nesfatin-1 concentrations in restricting-type anorexia nervosa. Peptide 32:150153.

Oh-I S, Shimizu H, Satoh T, Okada S, Adachi S, Inoue $\mathrm{K}$, Eguchi $\mathrm{H}$, Yamamoto M, Imaki T, Hashimoto K, Tsuchiya T, Monden T, Horiguchi K, Yamada M, Mori M (2006) Identification of nesfatin-1 as a satiety molecule in the hypothalamus. Nature 443: 709-712.

Okere B, Xu L, Roubos EW, Sonetti D, Kozicz T (2010) Restraint stress alters the secretory activity of neurons co-expressing urocortin-1, cocaine- and amphetamine-regulated transcript peptide and nesfatin-1 in the mouse Edinger-Westphal nucleus. Brain Res 1317:92-99.

Osaki A, Shimizu H, Ishizuka N, Suzuki Y, Mori M, Inoue $S$ (2012). Enhanced expression of nesfatin/ nucleobindin-2 in white adipose tissue of ventromedial hypothalamus-lesioned rats. Neurosci Lett 521:46-51.

Pałasz A, Krzystanek M, Worthington J, Czajkowska B, Kostro K, Wiaderkiewicz R, Bajor G (2012) Nesfatin-1, a unique regulatory neuropeptide of the brain. Neuropeptides 46:105-112.

Price CJ, Samson WK, Ferguson AV (2008) Nesfatin-1 inhibits NPY neurons in the arcuate nucleus. Brain Res 1230:99-106.

Ramanjaneya M, Chen J, Brown JE, Tripathi G, Hallschmid M, Patel S, Kern W, Hillhouse EW, Lehnert H, Tan BK, Randeva HS (2010) Identification of nesfatin-1 in human and murine adipose tissue: a novel depot-specific adipokine with increased levels in obesity. Endocrinology 151:3169-3180.

Shimizu H, Oh-I S, Hashimoto K, Nakata M, Yamamoto S, Yoshida N, Eguchi H, Kato I, Inoue K, Satoh T, Okada S, Yamada M, Yada T, Mori M (2009b) Peripheral administration of nesfatin-1 reduces food intake in mice: the leptin-independent mechanism. Endocrinology 150:662-671.

Shimizu H, Oh-I S, Okada S, Mori M (2009c) Nesfatin-1: an overview and future clinical application. Endocr. J 56:537-543.

Shimizu H, Ohsaki A, Oh-I S, Okada S, Mori M (2009a) A new anorexigenic protein, nesfatin-1. Peptides 30: 995-998.

Sonoda Y, Mukaida N, Wang JB, Shimada-Hiratsuka M, Naito M, Kasahara T, Harada A, Inoue M, Matsushima K (1998) Physiologic regulation of postovulatory neutrophil migration into vagina in mice by a C-X-C chemokine (s). J Immunol 160: 6159-6165.

Steffl M, Telgen L, Schweiger M, Amselgruber WM (2010) Estrous cycle-dependent activity of neutrophils in the porcine endometrium: possible involvement of heat shock protein 27 and lactoferrin. Anim Reprod Sci 121:159-166.

Stengel A, Goebel M, Jawien J, Kobelt P, Taché Y, Lambrecht NW (2011) Lipopolysaccharide increases gastric and circulating NUCB2/nesfatin-1 concentrations in rats. Peptides 32:1942-1947.

Stengel A, Goebel M, Taché Y (2010a) Nesfatin-1: a novel inhibitory regulator of food intake and body weight. Obes Rev 12:261-271.

Stengel A, Goebel M, Wang L, Kato I, Mori M, Taché Y (2012a) Nesfatin-130-59 but not the N- and Cterminal fragments, nesfatin-11-29 and nesfatin-16082 injected intracerebroventricularly decreases dark phase food intake by increasing inter-meal intervals in mice. Peptides 35:143-148.

Stengel A, Goebel M, Wang L, Rivier J, Kobelt P, Mönnikes H, Lambrecht NW, Taché Y (2009a) Central nesfatin- 
1 reduces darkphase food intake and gastric emptying in rats: differential role of corticotropin-releasing factor 2 receptor. Endocrinology 150:4911-4919.

Stengel A, Goebel M, Wang L, Taché Y (2009b) Ghrelin, des-acyl ghrelin and nesfatin-1 in gastric X/A-like cells: role as regulators of food intake and body weight. Peptides 31:357-369.

Stengel A, Goebel M, Wang L, Taché Y (2010b) Abdominal surgery activates nesfatin-1 immunoreactive brain nuclei in rats. Peptides 31:263-270.

Stengel A, Goebel M, Yakubov I, Wang L, Witcher D, Coskun T, Taché Y, Sachs G, Lambrecht NW (2009c) Identification and characterization of nesfatin-1 immunoreactivity in endocrine cell types of the rat gastric oxyntic mucosa. Endocrinology 150:232-238.

Stengel A, Taché Y (2010) Nesfatin-1 - role as possible new potent regulator of food intake. Regl Pept 163: 18-23.

Stengel A, Taché Y (2012) Gastric peptides and their regulation of hunger and satiety. Curr Gastroenterol Rep 14:480-488.

Su Y, Zhang J, Tang Y, Bi F, Liu JN (2010) The novel function of nesfatin-1: Anti-hyperglycemia. Biochem Biophys Res Commun 391:1039-1042.

Tagaya Y, Miura A, Okada S, Ohshima K, Mori M (2012a) Nucleobindin-2 is a positive modulator of EGF-dependent signals leading to enhancement of cell growth and suppression of adipocyte differentiation. Endocrinology 153:3308-3319.

Tagaya Y, Osaki A, Miura A, Okada S, Ohshima K, Hashimoto K, Yamada M, Satoh T, Shimizu H, Mori M (2012b) Secreted nucleobindin-2 inhibits 3T3-L1 adipocyte differentiation. Protein Pept Lett 19:997-1004.

Tang CH, Fu XJ, Xu XL, Wei XJ, Pan HS (2012) The anti-inflammatory and anti-apoptotic effects of nesfatin-1 in the traumatic rat brain. Peptides 36:39-45.

Tsuchiya T, Shimizu H, Yamada M, Osaki A, Oh-I S, Ariyama Y, Takahashi H, Okada S, Hashimoto K,
Satoh T, Kojima M, Mori M (2010) Fasting concentrations of nesfatin-1 are negatively correlated with body mass index in non-obese males. Clin Endocrinol 73:484-490.

Xia ZF, Fritze DM, Li JY, Chai B, Zhang C, Zhang W, Mulholland MW (2012) Nesfatin-1 inhibits gastric acid secretion via a central vagal mechanism in rats. Am J Physiol Gastrointest Liver Physiol 303: 570-577.

Xu L, Bloem B, Gaszner B, Roubos EW, Kozicz T (2009) Sex-specific effects of fasting on urocortin 1, cocaine-and amphetamine-regulated transcript peptide and nesfatin-1 expression in the rat Edinger-Westphal nucleus. Neuroscience 162:1141-1149.

Xu L, Bloem B, Gaszner B, Roubos EW, Kozicz T (2010) Stress-related changes in the activity of cocaine-and amphetamine-regulated transcript and nesfatin neurons in the midbrain non-preganglionic Edinger-Westphal nucleus in the rat. Neuroscience 170:478-488.

Yamawaki H, Takahashi M, Mukohda M, Morita T, Okada M, Hara Y (2012) A novel adipocytokine, nesfatin-1 modulates peripheral arterial contractility and blood pressure in rats. Biochem Biophys Res Commun 418:676-681.

Yang M, Zhang Z, Wang C, Li K, Li S, Boden G, Li L, Yang G (2012) Nesfatin-1 action in the brain increases insulin sensitivity through Akt/AMPK/ TORC2 pathway in diet-induced insulin resistance. Diabetes 61:1959-1968.

Yosten GL, Redlinger L, Samson WK (2012) Evidence for a role of endogenous nesfatin-1 in the control of water drinking. J Neuroendocrinol 24:1078-1084. Yosten GL, Samson WK (2009) Nesfatin-1 exerts cardiovascular actions in brain: possible interaction with the central melanocortin system. Am J Physiol Regul Integr Comp Physiol 297:330-336.

Yosten GL, Samson WK (2010) The anorexigenic and hypertensive effects of nesfatin-1 are reversed by 
pretreatment with an oxytocin receptor antagonist.

Am J Physiol Regul Integr Comp Physiol 298: 1642-1647.

Zhang AQ, Li XL, Jiang CY, Lin L, Shi RH, Chen JD, Oomura Y (2010) Expression of nesfatin-1/NUCB2 in rodent digestive system. World J Gastroenterol 16:1735-1741.

(Received 6 November 2012, Received in revised form 19 December 2012, Accepted 20 December 2012) 